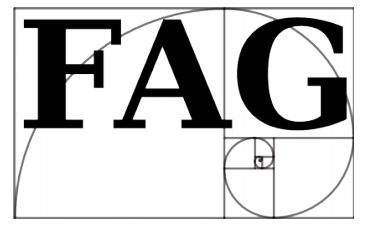

Filozoficzne Aspekty Genezy — 2017, t. 14

Philosophical Aspects of Origin

s. $89-98$

ISSN 2299-0356

http://www.nauka-a-religia.uz.zgora.pl/images/FAG/2017.t.14/art.03.pdf

Tom Gilson

\title{
Naturalizm metodologiczny, teizm metodologiczny i regularyzm
}

\begin{abstract}
Moja praktyka jako naukowca jest ateistyczna. Znaczy to, że gdy planuję eksperyment, zakładam, że żaden bóg, anioł czy diabeł nie zakłóci jego przebiegu. Założenie to znajduje uzasadnienie na przykład w sukcesach, jakie osiągnąłem w mojej karierze zawodowej. Byłbym więc intelektualnie nieuczciwy, gdybym nie miał ateistycznego nastawienia także w sprawach świata.
\end{abstract}

— J.B.S. Haldane (1892-1964), genetyk

Naukowcy zazwyczaj uzasadniają naturalizm metodologiczny na tej podstawie, że to, co nadnaturalne (lub pozanaturalne), nie jest testowalne, że wprowadzenie do nauki tego, co nadnaturalne (lub pozanaturalne), podważyłoby naukową metodologię i procesy rozumowania, oraz że naturalizm metodologiczny okazał się skuteczny. Te bezsprzeczne zalety naturalizmu metodologicznego są jednak silnie związane z nienaukowymi założeniami metafizycznymi, które zdominowały myślenie naukowe, mimo że nie wynikają one nieuchronnie z założeń naturalizmu metodologicznego. $\mathrm{Z}$ tego powodu potrzebna jest metafizycznie neutralna alternatywa - taka, która zachowuje zalety naturalizmu metodologicznego, odrzucając jednak stowarzyszone z nią nienaukowe założenia. Regularyzm, zdefiniowany jedynie (i celowo po prostu) jako „metodologiczne ocze-

\footnotetext{
Toм GiLson - ThinkingChristian.net. Genezy.

(C) Copyright by Tom Gilson, Blyth Institute Press, Dariusz Sagan \& Filozoficzne Aspekty

* Tom Gilson, „Methodological Naturalism, Methodological Theism, and Regularism”, w: Jonathan Bartlett and Eric Holloway (eds.), Naturalism and Its Alternatives in Scientific Methodologies: Proceedings of the 2016 Conference on Alternatives to Methodological Naturalism, Blyth Institute Press, Broken Arrow, Oklahoma 2017, s. 39-46. Za zgodą Autora i Wydawnictwa z języka angielskiego przełożył: Dariusz SAGAN.
} 
kiwanie niezawodnej regularności przyczyny i skutku w przyrodzie", spełnia te kryteria i zalecany jest jako lepsza alternatywa dla naturalizmu metodologicznego. ${ }^{1}$

\section{Wprowadzenie}

Trudno znaleźć jaśniejsze, bardziej zwięzłe sformułowanie tego funkcjonalnego poglądu, który zyskał akceptację większości naukowców. Bóg - lub przynajmniej Jego ingerencja - jest wykluczony z badań laboratoryjnych i wydaje się, że istnieje po temu dobry powód. Ponieważ nauka to badanie porządku naturalnego, a jej sukces zależy od założenia, że porządek naturalny jest zarówno naturalny, jak i uporządkowany, więc każda siła nadnaturalna, która by się weń wtrącała, wprowadzałaby tylko zamęt.

Zasadę tę doskonale ilustruje rysunek Sidneya Harrisa. Dwóch mężczyzn $\mathrm{w}$ fartuchach laboratoryjnych stoi przy tablicy. Po jej lewej i prawej stronie roi się od wzorów matematycznych, a pomiędzy nimi pojawia się zdanie „teraz następuje cud”. Jeden z naukowców wskazuje to zdanie i mówi: „myślę, że powinieneś doprecyzować drugi krok dowodu". Wszystkich to oczywiście śmieszy, nawet tych, którzy wierzą, że cuda rzeczywiście mogą się zdarzać.

Nauka nie zabrnie zbyt daleko, jeśli dopuści cuda jako wyjaśnienia procesów naturalnych. Być może przyroda nie jest wszystkim, co istnieje, ale nauka musi postępować tak, jak gdyby było to prawdą. Niech ludzie spierają się o bogów, anioły i demony, ale ze względów metodologicznych naukowcy muszą zakładać naturalizm. To znaczy zakładają oni, że nie istnieje nic (lub przynajmniej nie zdarza się nic) poza skutkami oddziaływania materii i energii w czasie i przestrzeni zachodzącego $\mathrm{w}$ zgodzie $\mathrm{z}$ regularnościami, które nazywamy prawami przyrody. Stąd bierze się naturalizm metodologiczny, jak pogląd ten jest na ogół określany. Jak wyraził się Robert Pennock, filozof nauki z Michigan State University:

Nauka wykorzystuje empiryczne zasady testowania obserwacyjnego. Hipotezy należy potwierdzać lub obalać w odniesieniu do danych empirycznych. Hipoteza zyskuje poparcie przez wykazanie, że potwierdzają się wynikające z niej konsekwencje, co prze-

\footnotetext{
${ }^{1}$ Niniejszy artykuł pierwotnie został opublikowany w czasopiśmie Touchstone i przedrukowano go tutaj za zgodą Redakcji.
} 
mawia za jej trafnością. [...] Teorie nadnaturalistyczne [...] nie mogą nam wskazać, co wynika lub nie wynika $\mathrm{z}$ ich nadnaturalnych składników. ${ }^{2}$

Chodzi też o coś więcej, ponieważ (jak kontynuuje Pennock) wprowadzenie do nauki tego, co nadnaturalne, podważyłoby naukową racjonalność. „Teraz następuje cud" to twierdzenie nie tylko nienaukowe. Jako zasada mająca umożliwiać zrozumienie regularnego funkcjonowania przyrody jest ono także irracjonalne.

Naturalizm nie ma jednak wyłącznie powiązań metodologicznych. Istnieje też naturalizm filozoficzny, który głosi nie tylko tyle, że naukowcy powinni postępować tak, jak gdyby naturalizm był prawdziwy, ale też że rzeczywiście jest on prawdziwy. Innymi słowy, rzeczywistość składa się jedynie z materii, energii, czasu, przestrzeni i praw przyrody. Jest to perspektywa w pełni ateistyczna i utrzymuje ją większość dzisiejszych ateistów, zwłaszcza tak zwani Nowi Ateiści. Na chwilę zostawmy to jednak na marginesie. Powinniśmy być w stanie się zgodzić, że bez względu na to, w co naukowiec wierzy wieczorami i w weekendy, wchodząc do laboratorium, staje się on praktykującym ateistą. Tylko to ma sens, prawda?

Nieprawda. Teizm judeochrześcijański prowadzi do dokładnie takich samych oczekiwań metodologicznych. Za podstawę nauki moglibyśmy równie dobrze uznać teizm metodologiczny.

$\mathrm{Na}$ szczęście, sugeruję to w bezpiecznym miejscu. Jestem pewny, że gdybym zaproponował teizm metodologiczny w określonych środowiskach akademickich, reakcja byłaby równie przewidywalna (i uwolniłaby równie dużo niepohamowanej energii), jak wybuchowa reakcja chemiczna w laboratorium Haldane'a: „Teizm!? Zwariowałeś! Nie możesz wprowadzać swoich religijnych przekonań do nauki! Nie ma w niej miejsca dla Boga!” Odpowiedziałbym (gdybym był w stanie przebić się przez wrzawę na sali), że tak naprawdę nie sugeruję, abyśmy podjęli próbę wprowadzenia teizmu czy to do laboratorium, czy do klas szkolnych. Mam na myśli co innego. „Teizm metodologiczny” to tylko krok prowadzący do innego wniosku. Jak w przypadku rusztowania, jest on użyteczny wyłącznie $\mathrm{w}$ trakcie budowy. Z pewnością towarzyszy mu zupełnie nie-

\footnotetext{
${ }^{2}$ Robert T. Pennock, Tower of Babel: The Evidence Against the New Creationism, $\mathrm{A} \mathrm{Brad}-$ ford Book, MIT Press, Cambridge, Massachusetts 1999, s. 195.
} 
dopuszczalne uprzedzenie, ale posługuję się nim tymczasowo po to tylko, aby ujawnić inne uprzedzenie, które także należy wyeliminować.

Zanim jednak dotrę do tego punktu, najpierw muszę pokazać, że teizm może pełnić tę samą funkcję, jaka spodziewana jest po naturalizmie. ${ }^{3}$

\section{Teizm i regularność przyrody}

Nauka wymaga, by przyroda była uporządkowana i przewidywalna. Wymaga tego również teizm. Nie jest to wyłącznie żydowskie czy chrześcijańskie dostosowanie się po fakcie do sukcesów metody naukowej. Jest to zawarte w samym jądrze teizmu chrześcijańskiego z co najmniej trzech powodów.

\subsection{Odpowiedzialność moralna czlowieka}

Po pierwsze, w myśl teizmu oczekuje się, że ludzie będą istotami odpowiedzialnymi moralnie. Zgodnie z teizmem Bóg dał nam wolną wolę, odpowiedzialność za wybór dobra lub zła i odpowiedzialność za nasze wybory moralne. Odpowiedzialność moralna jest nierozerwalnie związana ze zdolnością przewidywania skutków naszych czynów. Mógłbym zilustrować to niezliczonymi przykładami, ale jeden powinien wystarczyć: czy matka jest moralnie odpowiedzialna za karmienie swojego dziecka pożywnym jedzeniem? Bez wątpienia. Przypuśćmy, że w niektóre dni brokuł jest wartościowym źródłem pożywienia, a w inne (lub dla innych dzieci w te same) dni skutki jego zjedzenia stają się nieprzewidywalne i z niewiadomych przyczyn śmiertelne. Załóżmy, że w międzyczasie pączki z polewą czekoladową (także tym razem nieprzewidywalnie oraz z niewiadomych przyczyn) stały się pokarmem najbardziej pożywnym. Czy można by obwiniać matkę za śmierć jej dziecka po spożyciu brokułów? Czy można by ją chwalić za to, że nie karmiła swojego dziecka pączkami? Nie. W kategoriach moralnych byłaby ona zupełnie bezradna. Nie ciążyłaby na niej odpowiedzialność moralna za takie wybory.

\footnotetext{
${ }^{3}$ Nawiasem mówiąc, teizm, o który mi chodzi, to teizm judeochrześcijański w takiej wersji, w jakiej uznawała go zdecydowana większość jego zwolenników w historii. Może mieć on zastosowanie do muzułmańskiego ujęcia Allaha, ale nie musi. Ciągłe mówienie o „teizmie judeochrześcijańskim” byłoby męczące, dlatego będę posługiwać się terminem „teizm”, ale należy przy tym pamiętać, że zawsze mam na myśli określony pogląd teistyczny.
} 


\subsection{Proces uczenia się czlowieka}

Po drugie, teizm zakłada, że ludzie będą potrafić uczyć się z doświadczenia i że tego chce dla nas Bóg. „Co człowiek sieje, to i żąć będzie” — powiada Pismo Święte. Przypuśćmy, że zasialiśmy jęczmień i jednego roku wyrosła pszenica, drugiego roku - owies, a trzeciego - drzewa orzechowe. Czego dowiedzielibyśmy się o skutkach posiania jęczmienia? Czy moglibyśmy w ogóle mówić, że zasialiśmy ziarno jęczmienia? Czy wiedzielibyśmy wystarczająco dużo, by nadać temu ziarnu jakąkolwiek nazwę? Albo co by było, gdyby nawadnianie lub nawozy niekiedy (nieprzewidywalnie i z niewiadomych przyczyn) niszczyły całą uprawę? Nie mielibyśmy żadnej wiedzy o rolnictwie. „Nawóz” nie stanowiłby tylko obcego pojęcia - na zawsze pozostawiłby puste miejsce w naszych umysłach. Z perspektywy wiedzy o tym, jak wyżywić rodzinę, a tym bardziej społeczeństwo, bylibyśmy niczym niemowlęta (lub mieszkańcy miast).

Regularność przyczyny i skutku jest ważna dla nauki, ale zanim powstała nauka, regularność ta była kluczowa również dla innych celów. Mężczyźni i kobiety dowiadywali się, z doświadczenia, skąd biorą się dzieci. Czy Boga to nie interesuje? Mógłbym mnożyć przykłady, ale pokazałem już to, co zamierzałem. Teizm wymaga istnienia uporządkowanych procesów przyrodniczych, dzięki którym możemy się uczyć.

\subsection{Komunikacja z Bogiem}

Po trzecie, teizm utrzymuje, że Bóg potrafi i (przynajmniej czasem) chce komunikować się z ludźmi w sposób zrozumiały. To także wymaga środowiska, które na ogół jest uporządkowane. Aby wyjaśnić powód tego, możemy posłużyć się terminem inżynierskim — stosunek sygnału do szumu. Rozważmy jaką́s rozmowę w cichym salonie, a następnie wyobraźmy sobie tę samą rozmowę w zatłoczonej restauracji z murowanymi ścianami i betonowymi podłogami, które zapewniają bardzo żywą akustykę. Poziom głośności rozmowy w pierwszym otoczeniu diametralnie różni się od wymaganego poziomu głośności rozmowy w drugim otoczeniu, w którym szum jest znacznie większy.

W inżynierii „szum” nie zawsze dotyczy dźwięku. Termin ten odnosi się do każdej funkcjonalnie losowej energii, która nie niesie żadnej użytecznej informacji. (Szumy w restauracji nie są, ściśle rzecz biorąc, losowe, ale sytuacja jest 
wystarczająco podobna, by nadawała się do naszych celów.) Aby jakikolwiek sygnał mógł zostać skutecznie wyrażony, zawsze potrzebny jest dostatecznie wysoki stosunek sygnału do szumu, umożliwiający rozstrzygnięcie, co naprawdę jest sygnałem, a co nie.

John B.S. Haldane wyobraził sobie, że cuda zakłócałyby eksperymenty laboratoryjne tak często, że nie bylibyśmy w stanie uprawiać nauki. Gdyby tak było - gdyby ingerencja Boga była zarówno częsta, jak i nieprzewidywalna cuda nie byłyby cudami, lecz szumem. Gdyby siekiery od czasu do czasu same wypływały z rzeki, to opowieść z 2 Księgi Królewskiej 6:1-6 nie byłaby na tyle interesująca, by mogła znaleźć miejsce w Biblii. Gdyby trędowaci ulegali niekiedy spontanicznemu uleczeniu, dotyk Jezusa znaczyłby niewiele. Gdyby ludzie losowo wstawali ze zmarłych, zmartwychwstanie Jezusa nie niosłoby żadnego przesłania.

Aby Bóg mógł komunikować się za pośrednictwem cudów, muszą być one naprawdę wyjątkowymi zdarzeniami i za takie właśnie uznaje je teizm. Opisane przez Haldane'a spektrum aniołów czy demonów unoszących się w laboratorium i zakłócających eksperymenty to fantazja podsunięta przez jego własną wyobraźnię. Nie ma to nic wspólnego z teizmem chrześcijańskim. Sporadyczny, rzadki cud w żaden sposób nie unieważnia metody naukowej. Naukowcy stale mają do czynienia $\mathrm{z}$ anomalnymi danymi i dysponują standardową procedurą postępowania w takich wypadkach: albo powtarzają eksperyment, uznając uzyskane dane za rezultat błędu statystycznego, albo ulepszają go i próbują od nowa. Taka praktyka nie jest w nauce czymś niespotykanym.

\subsection{Teizm i moralny fundament nauki}

W nauce wymagana jest też inna cnota - uczciwość. Teizm mówi o tym od dawna. Wyzwaniem byłoby znalezienie przekonującego powodu do mówienia prawdy w ramach naturalizmu, który sam z siebie nie zapewnia żadnych wymogów etycznych. Naturaliści na ogół mówią o robieniu tego, co najlepiej sprawdza się w realizacji różnych celów: rozkwitu ludzkości, spełnienia pragnień lub maksymalizacji tego, co dobre dla człowieka - wliczając w to postęp nauki. Sa to jednak tylko ludzkie dodatki do zupełnie amoralnego i bezosobowego naturalistycznego substratu. Natomiast teizm postrzega uczciwość jako fundamentalną 
cnotę, która pokazuje, że prawdziwa natura rzeczywistości ma źródło w prawdziwie osobowym Bogu.

\section{Niedopuszczalne metafizyczne uprzedzenia}

Pod pewnym względem teizm metodologiczny ma tyle samo sensu, co naturalizm metodologiczny. Pełni tę samą rolę dla nauki, jak naturalizm metodologiczny: daje oczekiwanie uporządkowania i przewidywalności. Uprzedzenie nadal stanowi jednak problem. Nauka nie powinna wprowadzać takiego metafizycznego założenia do laboratorium lub, w szczególności, do klas szkolnych. $\mathrm{Z}$ tego powodu nie proponuję teizmu metodologicznego jako uniwersalnej zasady, pod którą mieliby podpisywać się naukowcy. (Teiści mogą to robić, ale nie powinni sugerować lub nakazywać jej jako ogólnej reguły innym naukowcom.) Bagaż metafizyczny nie należy do nauki. Sądzę, że wszyscy naukowcy powinni się z tym zgodzić. Dlatego wtaśnie naturalizm metodologiczny również nie powinien być uznawany za odpowiednia zasadę dla nauki. Naturalizm, w równym stopniu jak teizm, jest przecież stanowiskiem metafizycznym. Dodanie przymiotnika „metodologiczny” do rzeczownika ,naturalizm” nie sprawia, że „naturalizm" przestaje być stanowiskiem metafizycznym, podobnie jak jest w przypadku „teizmu”, co do którego nikt nie wątpi, że jest stanowiskiem obciążonym niedopuszczalnym uprzedzeniem. Przypomnijmy sobie, co powiedział Haldane: ${ }^{4}$ „Byłbym więc intelektualnie nieuczciwy, gdybym nie miał ateistycznego nastawienia także w sprawach świata".

Lawrence Krauss, profesor fizyki z Arizona State University, zauważył, że Haldane

rozumiał, że nauka jest dyscypliną z konieczności ateistyczną. Haldane trafnie opisał, że nie da się dokonywać odkryć naukowych, jeśli założy się, że „bóg, anioł lub diabel” może zakłócać eksperymenty. Bóg jest, z konieczności, nieistotny dla nauki.

W obliczu zdumiewającego sukcesu nauki w wyjaśnianiu funkcjonowania świata fizycznego wielu, a prawdopodobnie większość, naukowców reaguje — co jest zupełnie zrozumiałe - dokładnie tak samo jak Haldane. Mianowicie ekstrapolują ateizm nauki na bardziej ogólny ateizm.

\footnotetext{
${ }^{4}$ Por. John B.S. Haldane, Faith and Fact, The Thinker's Library, vol. 44, Watts \& Company, London 1934.
} 
Mimo że taki przeskok może nie być w pełni uzasadniony, to z pewnością jest racjonalny. [...] Chociaż nauka może być spójna z ogólnikową ideą jakiegoś bóstwa, które tylko zapoczątkowało Wszechświat i pozwoliło mu na samodzielny rozwój, to nie jest ona racjonalnie zgodna ze szczegółowymi zasadami większości światowych religii zinstytucjonalizowanych. ${ }^{5}$

Być może Krauss nie jest świadomy, że wprowadza tu fałszywą dychotomię. Widzi tylko dwie możliwości: albo Bóg ingeruje w świat, przez co nauka jest niemożliwa, albo jedynie ,zapoczątkował Wszechświat i pozwala mu na samodzielny rozwój”. Zgodnie jednak z trzecią możliwością — która, w przeciwieństwie do tego, co mówi Krauss, należycie opisuje żydowską i chrześcijańską doktrynę - Bóg ustanowił porządek naturalny, który przez niemal cały czas funkcjonuje w sposób regularny, zaś wyjątki zachodzą niezwykle rzadko. W nauce nie trzeba zakładać żadnej odmiany naturalizmu.

\section{Regularyzm jako alternatywa}

Nauka wymaga wyłącznie, aby przyroda funkcjonowała w sposób regularny. Tyle właśnie zapewnia nauce, na poziomie pojęciowym, naturalizm metodologiczny. Nauka nie wymaga przedkładania jednego metafizycznego punktu widzenia nad inny, o ile oba te punkty widzenia mówią o świecie dostatecznie uporządkowanym i regularnym. (Teizm może dostarczać lepszych racji do oczekiwania, by przyroda zachowywała się w sposób regularny, ale jest to temat na inną dyskusję.) Tak więc ani naturalizm metodologiczny, ani teizm metodologiczny nie stanowią odpowiedniej uniwersalnej zasady, której powinni przestrzegać czynni naukowcy. Potrzebujemy w zamian czegoś metafizycznie neutralnego. Prawdopodobnie potrzebujemy czegoś, co będzie się sprawdzać zarówno w laboratorium, jak i w życiu codziennym, tak aby Haldane, Krauss lub ktokolwiek inny, łącznie z naukowcami chrześcijańskimi, mogli żyć podług tej samej zasady czy to wtedy, gdy zakładają fartuchy laboratoryjne, czy wówczas, gdy je ściągają. Potrzebujemy czegoś, co mówi jedynie o regularnym funkcjonowaniu przyrody.

Trudno znaleźć coś prostszego niż właśnie słowo „regularny”. W konkluzji proponuję więc, abyśmy porzucili przymiotnik „metodologiczny” — a przy tym

\footnotetext{
${ }^{5}$ Lawrence Krauss, „God and Science Don’t Mix”, Wall Street Journal 2009, http://www. wsj.com/articles/SB124597314928257169 (26.11.2017).
} 
całą jego metafizyczną otoczkę - i zdali sobie sprawę, że nauka, podobnie jak całe życie, funkcjonuje w zgodzie $\mathrm{z}$ oczekiwaniem przyrodniczej regularności. Jeżeli do opisania odpowiedniego stanowiska musimy posłużyć się „,izmem”, to użyjmy słowa regularyzm. Jest to niemal rozczarowująco proste. Trudno dodać coś jeszcze na ten temat, nawet w tym miejscu artykułu, w którym wprowadzam ten termin. Regularyzm, jako pogląd na rzeczywistość, jest skrajnie ubogi $\mathrm{w}$ treść. Można go pogodzić równie dobrze zarówno $\mathrm{z}$ teizmem, jak i naturalizmem. Mówi dokładnie to, co należy powiedzieć. Nie wnosi żadnej nieistotnej metafizyki, niczego nienaukowego, niczego, co trzeba by założyć lub ściągnąć przy drzwiach laboratorium. Jest to lepsza alternatywa dla metafizycznie obciążonego terminu ,naturalizm metodologiczny”. Jest to też lepszy sposób pojmowania, jak uprawia się naukę.

Tom Gilson

\section{Bibliografia}

Haldane John B.S., Faith and Fact, The Thinker's Library, vol. 44, Watts \& Company, London 1934.

Krauss Lawrence, „God and Science Don’t Mix”, Wall Street Journal 2009, http://www. wsj.com/articles/SB124597314928257169 (26.11.2017).

Pennock Robert T., Tower of Babel: The Evidence Against the New Creationism, A Bradford Book, MIT Press, Cambridge, Massachusetts 1999.

\section{Naturalizm metodologiczny, teizm metodologiczny i regularyzm}

\section{Streszczenie}

Naukowcy zazwyczaj uzasadniają naturalizm metodologiczny na tej podstawie, że to, co nadnaturalne (lub pozanaturalne), nie jest testowalne, że wprowadzenie do nauki tego, co nadnaturalne (lub pozanaturalne), podważyłoby naukową metodologię i procesy rozumowania, oraz że naturalizm metodologiczny okazał się skuteczny. Te bezsprzeczne zalety naturalizmu metodologicznego są jednak silnie związane z nienaukowymi założeniami metafizycznymi, które zdominowały myślenie naukowe, mimo że nie wynikają one nieuchronnie $\mathrm{z}$ założeń naturalizmu metodologicznego. $\mathrm{Z}$ tego powodu potrzebna jest metafizycznie neutralna alternatywa - taka, która zachowuje zalety naturalizmu metodologicznego, odrzucając jednak stowarzyszone z nią nienaukowe założenia. Regularyzm, zdefiniowany jedynie (i celowo po prostu) jako „metodologiczne oczekiwanie niezawodnej regularności 
przyczyny i skutku w przyrodzie", spełnia te kryteria i zalecany jest jako lepsza alternatywa dla naturalizmu metodologicznego.

Slowa kluczowe: naturalizm metodologiczny, naturalizm filozoficzny, teizm judeochrześcijański, teizm metodologiczny, założenia metafizyczne, regularyzm, nauka.

\section{Methodological Naturalism, Methodological Theism, and Regularism}

\section{Summary}

Scientists typically justify methodological naturalism on grounds that the supernatural (or extra-natural) is not testable, that admitting the supernatural (or extra-natural) into science would undermine scientific methodology and reasoning processes, and that methodological naturalism has been demonstrated to be effective. These admitted virtues of methodological naturalism are strongly associated, however, with unscientific metaphysical assumptions which tend to dominate scientific thinking even if they do not follow necessarily from methodological naturalism's assumptions. For that reason a metaphysically neutral alternative is called for, one that retains methodological naturalism's virtues while discarding its associated unscientific assumptions. Regularism, defined merely (and intentionally quite simply) as ,the methodological expectation of reliable regularity of cause and effect in nature", fits these criteria, and is recommended as a superior alternative to methodological naturalism.

Keywords: methodological naturalism, philosophical naturalism, Judeo-Christian theism, methodological theism, metaphysical assumptions, regularism, science. 